\title{
Opioid Complications and Side Effects
}

\author{
Ramsin Benyamin, MD', Andrea M. Trescot, MD², Sukdeb Datta, MD², \\ Ricardo Buenaventura, MD4, Rajive Adlaka, MD', Nalini Sehgal, MD', \\ Scott E. Glaser, $\mathrm{MD}^{7}$, and Ricardo Vallejo, $\mathrm{MD}^{8}$
}

From: ${ }^{1,8}$ Millennium Pain Center, Bloomington, IL; 2University of Florida, Gainesville, FL, Malcom Randall VA Medical Center; 'Banderbilt University School of Medicine, Nashville, TN; 4Dayton Pain Med, Kettering, $\mathrm{OH}$; 5 Pain Control Associates, Munster, IN; ${ }^{6}$ University of Wisconsin School of Medicine and Public Health, Madison, WI; ' .Pain Specialists of Greater Chicago, Burr Ridge, IL; and ${ }^{8}$ Millennium Pain Center=, bloomingtn IL, Illinois State University, Normal, IL;

Dr. Benyamin is President, Millennium Pain Center, Clinical Associate Professor, Department of Surgery, College of Medicine, University of Illinois, Urbana-Champaign, IL. Dr. Trescot is Director of the Pain Fellowship Program at the University of Florida and the Malcolm Randal VA Medical Center, Gainesville, FL. Dr. Datta is Director, Vanderbilt University

Interventional Pain Program, Associate Professor,

Dept. of Anesthesiology, Vanderbilt University Medical Center, Nashville, TN.

Dr. Buenaventura is Medical Director, Dayton Pain Med, and Clinical Associate Professor, Department of Surgery, Wright State University School of Medicine,

Dayton, $\mathrm{OH}$.

Dr. Adlaka is the Medical Director of Pain Control Associates Munster, IN.

Dr. Sehgal is the Director of the Interventional Pain

Program at the University of Wisconsin School of Medicine and Public Health and Associate Professor Rehabilitation Medicine, Madison, WI.

Dr. Glaser is Director of the Pain Specialists of Greater Chicago, Burr Ridge, IL.

Dr. Vallejo is Director of Research, Staff Pain Medicine, Millennium Pain Center, Bloomington, IL; and Adjunct Professor of Biology, Illinois State University, Normal, IL.

Address correspondence: Ramsin Benyamin, MD Millennium Pain Center 1015 S. Mercer Ave.

Bloomington, IL 61701

E-mail: benyamin@millenniumpaincenter.com

Funding: Internal funding was provided by American Society of Interventional Pain Physicians limited to travel and lodging expenses of the authors.

Conflict of Interest: None

Free full manuscript:
Medications which bind to opioid receptors are increasingly being prescribed for the treatment of multiple and diverse chronic painful conditions. Their use for acute pain or terminal pain is well accepted. Their role in the long-term treatment of chronic noncancer pain is, however, controversial for many reasons. One of the primary reasons is the well-known phenomenon of psychological addiction that can occur with the use of these medications. Abuse and diversion of these medications is a growing problem as the availability of these medications increases and this public health issue confounds their clinical utility. Also, the extent of their efficacy in the treatment of pain when utilized on a chronic basis has not been definitively proven. Lastly, the role of opioids in the treatment of chronic pain is also influenced by the fact that these potent analgesics are associated with a significant number of side effects and complications. It is these phenomena that are the focus of this review.

Common side effects of opioid administration include sedation, dizziness, nausea, vomiting, constipation, physical dependence, tolerance, and respiratory depression. Physical dependence and addiction are clinical concerns that may prevent proper prescribing and in turn inadequate pain management. Less common side effects may include delayed gastric emptying, hyperalgesia, immunologic and hormonal dysfunction, muscle rigidity, and myoclonus. The most common side effects of opioid usage are constipation (which has a very high incidence) and nausea. These 2 side effects can be difficult to manage and frequently tolerance to them does not develop; this is especially true for constipation. They may be severe enough to require opioid discontinuation, and contribute to under-dosing and inadequate analgesia. Several clinical trials are underway to identify adjunct therapies that may mitigate these side effects. Switching opioids and/or routes of administration may also provide benefits for patients. Proper patient screening, education, and preemptive treatment of potential side effects may aid in maximizing effectiveness while reducing the severity of side effects and adverse events. Opioids can be considered broad spectrum analgesic agents, affecting a wide number of organ systems and influencing a large number of body functions.

Key words: Opioids, morphine, methadone, fentsnyl, oxycodone, hydrocodone, xymorphone, codeine, adverse events, narcotics, side effects, constipation, sedation, hearing loss, tolerance, addiction, hyperalgesia

Pain Physician 2008; 11:S105-S120 


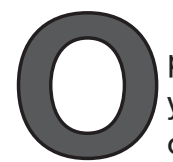
pioids have been used for thousands of years for the treatment of acute and chronic pain. Around 3400 B.C., the opium poppy was cultivated in lower Mesopotamia by Sumerians who referred to it as Hul Gil, the "joy plant." The Sumerians passed along the plant and its euphoric effects to the Assyrians and Babylonians who in turn would pass their knowledge onto the Egyptians. Ancient Egyptian papyrus records mention opium as a treatment for pain (1), and in 1170, the first book of western surgery described using sponges soaked in opium held over the patient's nose for surgical procedures (2). Their use in America has waxed and waned based on multiple and disparate factors including availability, the introduction of new methods of administration, regulatory efforts, and physician and societal attitudes. Currently, the prescribing of opioids has escalated dramatically for a variety of reasons in the United States. Unfortunately, but not unexpectedly, this has also been accompanied by a concomitant and dramatic rise in the incidence of diversion and abuse of these medications as well as the incidence of complications including overdosage and death.

Currently, statistics show that approximately $90 \%$ of patients with chronic pain receive opioids (3-26), and $90 \%$ of patients presenting to an interventional pain management center are already on opioids (27). It is estimated that the prevalence of a substance abuse disorder is $8.1 \%$ in the general population (28) and even higher in the population of patients with chronic pain (20-26). These facts explain the dramatic rise in prescription drug abuse and in complications secondary to controlled substances. One study showed that $16 \%$ of active pain patients were found to be abusing their medications (21). In another study, Manchikanti et al (22) reviewed the records of almost 5,500 patients, and found 91 deaths, of which 18 were drug poisoning deaths. Of those, 12 were felt to be partially or significantly due to prescription drugs.

Other side effects, such as constipation, nausea and vomiting, respiratory depression, and sedation often limit the dosing and effectiveness of opioids, leading to early discontinuation, under-dosing, and inadequate analgesia. Appropriate identification and management of these side effects would be expected to improve patient compliance and medication efficacy and reduce complications.

For many years, the use of opioids for noncancer pain was limited but this has changed secondary to recent efforts to address the lack of recognition and under-treatment of chronic pain by the medical professionals. These efforts include the regulatory requirement of hospitals to evaluate and address "pain," education by advocacy pain organizations, and aggressive marketing by prescription opioid manufacturers to physicians of all specialties. The confluence of these efforts has contributed to a recent dramatic increase in opioid prescribing.

Although the following clinical statement may be intuitive to most physicians, its importance cannot be overstated when utilizing opioids for the treatment of chronic noncancer pain. Opioids should be prescribed at the lowest dose possible to provide adequate analgesia for improvement in the quality of the patient's life and for improvement in function. Complete pain relief may occur but this is uncommon and cannot be considered a treatment goal. The patient must be educated regarding these goals and continually reminded during the course of treatment. Opioids should not be used in isolation to treat pain and the goals of treatment will commonly require additional medications such as anticonvulsants, antidepressants, NSAIDs, and other adjuvant treatments as well as nonpharmacologic strategies. While advocacy for appropriate opioid usage in chronic pain continues, it is well known that prolonged use of opioids may result in adverse consequences, including tolerance, hyperalgesia, hormonal effects, and immunosuppression.

\section{Opioid Tolerance and Physical Dependence}

Tolerance, a loss of analgesic potency, is one of the common complications of opioid treatment, leading to ever-increasing dose requirements and decreasing effectiveness over time. Physical dependence is the development of an altered physiological state that is revealed by an opioid withdrawal syndrome involving autonomic and somatic hyperactivity. There are 2 types of tolerance: innate (which is genetically determined and would be present from the initial dose of the opioid) and acquired (pharmacokinetic, pharmacodynamic, and learned) (29). Pharmacokinetic tolerance results from changes in the metabolism of a drug after repeated administration, such as the induction of an enzyme by the administration of the drug itself (as seen with initiation of methadone treatment). Pharmacodynamic tolerance is represented by the classic decreased effectiveness of an opioid over time, related to up-regulation of receptors. Learned toler- 
ance, on the other hand, results in a decrease in efficacy as compensatory mechanisms are incorporated or learned. For instance, a patient in a setting where he or she usually consumes the drug typically expects the drug to be less effective; however, if the same person takes the same amount of drug in a nonstandard setting, he or she will likely feel a greater effect (30).

One concern when starting a patient on long-term opioids has to be whether efficacy can be maintained over time. Both acute and chronic administration of opioids may produce tolerance as indicated by the lowering analgesic effects of the same dose over time. Since the initial studies by Light and Torrance in the 1920s, the major focus on research for tolerance has been its relationship to physical and psychological dependence (31). Since tolerance was considered to be the driving force to support the street addicts' abuse of opioids, there was a notion that it would occur in a similar way if opioids were used on a chronic basis in patients with chronic pain. Physicians were reluctant to use opioids and preferred to use them in a restrictive manner to preserve their efficacy for a situation when they were really needed. However, there are no studies to support this point of view. Interestingly, it seems that tolerance develops at a different rate depending on the specific opioid prescribed.

Although short-term studies have shown opioid efficacy for 4 to 32 weeks, it is not ethically possible to do placebo controlled randomized opioid trials, so the only knowledge of long-term analgesia comes from surveys, case series, open-label studies, and epidemiologic studies (32). When prescribing opioids, clinicians should be aware of the lack of complete cross tolerance. That is, the development of tolerance to one particular opioid doesn't necessarily confer tolerance to another. The clinical significance of this fact is paramount, as prescription of a new opioid at equianalgesic doses may lead to overdose.

Recent evidence suggests that spinal adaptations leading to increased activity of sensory neuropeptides, such as calcitonin gene-related peptide (CGRP) and substance $P$, and their downstream signaling messengers derived from metabolism of arachidonic acid such as prostaglandins (PG), lipoxygenase (LOX) metabolites, and endocannabinoids, play an important role in the tolerance phenomenon (33).

In mice, NMDA receptor antagonists block the development of tolerance to morphine, but not fentanyl or a pure delta opioid receptor agonist; few similar studies in humans have been performed. It is also striking that patients on chronic opioids such as methadone have dramatically decreased tolerance to experimental pain (such as a cold pressor test) compared to patients on no opioids (20 seconds compared to 1 minute), despite additional high doses of morphine (34).

In conclusion, although tolerance is a well known physiologic phenomena, its clinical relevance is unknown. Further studies to determine appropriate methods to decrease its development and to determine its relevance are warranted.

\section{Opioid-induced Immunologic Effects}

The immunomodulatory effects of opioids were initially demonstrated in the 1890s when Cantacuzene showed cellular immune suppression and decreased resistance to bacterial infection in guinea pigs treated with morphine. Opioids have been implicated in the increased incidence of infections in heroin addicts and as a cofactor in the pathogenesis of human immunodeficiency virus. Interestingly, although exogenous opioids may generate immunosuppression, their endogenous counterparts (e.g., endorphins), induce immunoactivation. It is known that acute and chronic opioid administration can cause inhibitory effects on antibody and cellular immune responses, natural killer cell activity, cytokine expression, and phagocytic activity. The immunologic effects of opioids are mediated by central and peripheral mechanisms. The potential mechanism by which central opioid receptors mediate peripheral immunosuppression may involve the hypothalamic-pituitary-adrenal axis and the autonomic nervous system. Interestingly, peripheral immune cells under the influence of cytokines, may release endogenous opioids modulating analgesia and inflammatory responses. Moreover, the same cells can express opioid receptors, creating a bi-directional system whereby opioids, immune cells, and cytokines dynamically interact (35-37).

The role of different central opioid receptors in the modulation of the immune response is variable (Table 1). Activation of KOR (kappa opioid receptor) and DOR (delta opioid receptor) may activate the cellular immune response $(38,39)$, while effects of MOR (mu opioid receptor) may be more related to natural killer (NK) cell activity, cytokine secretion, and macrophage phagocytosis. Probably related to the affinity of different opioids to a particular receptor is the finding that mice injected with morphine had a biphasic immune response (40) with an increase in polymorpho- 
Table 1. Central immunologic effects of opioids.

\begin{tabular}{|l|l|}
\hline Receptor & Effect \\
\hline MOR & $\begin{array}{l}\text { Decreases NK cell activity (central) } \\
\text { Macrophage phagocytosis (central) } \\
\text { Inhibits T-cell proliferation (central) } \\
\text { Nitric oxide release (peripheral) }\end{array}$ \\
\hline DOR & $\begin{array}{l}\text { Increases NK cell activity (central) } \\
\text { Potentiates humoral immune response (MOR } \\
\text { dependent) } \\
\text { Decreases PFC response }\end{array}$ \\
\hline $\begin{array}{l}\text { DOR } \\
\text { antagonist }\end{array}$ & \begin{tabular}{l} 
At low dose inhibits DHR \\
\hline KOR
\end{tabular} \\
\hline $\begin{array}{l}\text { KOR } \\
\text { antagonist }\end{array}$ & $\begin{array}{l}\text { Increases PFC } \\
\text { Suppression of humoral immune response } \\
\text { (MOR dependent) }\end{array}$ \\
\hline
\end{tabular}

$\mathrm{PFC}=$ plaque forming cells; $\mathrm{DHR}=$ delayed hypersensitivity reaction; $\mathrm{NK}=$ natural killer

nuclear phagocytosis, followed by a marked decrease 24 hours later. Methadone, however, in an equianalgesic dose did not affect the tested immunoparameters. In clinical practice, not all opioids have similar effects on the immune system. Particular reference needs to be made to tramadol, which enhances NK cell activity, lymphocyte proliferation, and IL-2 release compared to morphine, while buprenorphine, with its mu agonist and kappa antagonist effects, doesn't show any effects on the immune response compared to morphine. It is important to remark that severe pain by itself has a significant immunosuppressive effect and although the use of certain opioids may potentially increase the risk of infection, the clinical significance of this relationship between pain, analgesia, and opioidinduced immunosuppression has not been clarified.

\section{Opioid-induced Hormonal Changes}

The effects of opioid compounds on hormonal function is now fairly well understood and has been termed opioid endocrinopathy (OE) (Table 2) or, in the case of androgen hormones, opioid-induced androgen deficiency (OPIAD) (41-43). The hormonal effects of opioid usage affect both men and women and have been documented during oral consumption (41,43-47) as well as transdermal (4,44-48), intravenous (49-52), and intrathecal $(53,54)$ administration. OE has also been documented in illicit drug users where serum hormone levels return to normal following withdrawal from the drug $(45,49,55,56)$. Various studies have demonstrated opioid effects on a variety of hormones including but not limited to testosterone (both total
Table 2. Opioid-induced hormonal changes.

\begin{tabular}{||l|l|l||}
\hline Hormone & Opioid Effect & Potential symptom linkage \\
\hline Testosterone & decrease & $\begin{array}{l}\text { decreased libido } \\
\text { erectile dysfunction } \\
\text { reduced energy }\end{array}$ \\
\hline Estrogen & decrease & $\begin{array}{l}\text { sexual dysfunction } \\
\text { reduced bone mineral density } \\
\text { osteoporosis }\end{array}$ \\
\hline Cortisol & decrease & secondary hormonal alterations \\
\hline $\begin{array}{l}\text { Luetenizing } \\
\text { hormone }\end{array}$ & decrease & $\begin{array}{l}\text { secondary reduced androgen } \\
\text { hormone levels } \\
\text { amenorrhea } \\
\text { hypomenorrhea }\end{array}$ \\
\hline $\begin{array}{l}\text { Gonadotropin } \\
\text { releasing } \\
\text { hormone }\end{array}$ & decrease & $\begin{array}{l}\text { secondary reduced androgen } \\
\text { hormone levels }\end{array}$ \\
\hline
\end{tabular}

and free) $(41,47)$, estrogen (estradiol, etc.) $(42,45$ 53), luteinizing hormone (LH) $(42,53)$, gonadotrophin releasing hormone $(\mathrm{GnRH})(51,57,58)$, dehydroepiandrosterone (DHEA) and dehydroepiandrosterone sulfates (DHEAS) (43), adrenocorticotropin (ACTH) and corticotropin-releasing hormone $(\mathrm{CRH})(48,59)$, and cortisol $(48,59)$. The majority of work has focused on the androgen hormones because of their linkage to many symptomatic side effects of opioid usage.

Many men who are taking prescribed or illicit opioids suffer from several side effects including sexual dysfunction (i.e., erectile dysfunction, decreased libido, etc.), depression, and decreased energy level. These unwanted side effects have been correlated to hypogonadism and likely hypogonadotrophic hypogonadism $(43,44,60,61)$. Testosterone levels are typically lowered $1-4$ hours after acute administration of opioids (45) and return to normal levels within 24 hours of stopping the opioid (62). Chronic administration of opioids for nonmalignant pain result in tonic decreases in both total (TT) and free (FT) testosterone levels in an apparent dose-dependent fashion $(41,47)$. It should be noted, however, that not all men show decreased TT levels and several physiological (e.g., Basal Metabolic Index) and behavioral measures (e.g., smoking) may predispose individuals to hormonal side effects of opioids (41). Also, it is not entirely clear that reduced testosterone directly contributes to sexual dysfunction. Through multivariate analyses Hallinan and colleagues concluded that testosterone levels contributed little variance in measures of sexual dysfunction (63). However, it should be noted that these 
data were obtained from addicts on methadone or buprenorphine maintenance treatment and may not entirely apply to patient populations taking opioids for nonmalignant chronic pain. Studies examining potential adjuvant therapies treating potential hormonally mediated side effects are rare. Daniell and colleagues (44) performed an open-label trial of testosterone replacement therapy in men taking opioids for chronic noncancer related pain. Although many men showed improvement in indexes of sexual function, mood, and well-being, the effects were generally incompletely resolved (44). Interestingly, the effects of opioids on testosterone may be dependent on the specific opioid utilized. Bliesener and colleagues (47) studied the hormonal effects of opioid maintenance and found that individuals taking buprenorphine had significantly higher plasma testosterone levels and showed less sexual dysfunction compared to patients receiving methadone.

Again, it is unclear if these results can be extrapolated to pain patient populations, but it underscores the importance of a potential for medication dependent hormonal side effects. Apart from circulating testosterone levels, adrenal androgens are also reduced in men on prescribed opioids $(42,45,53)$. These latter findings suggest that opioids may not only affect hypothamic-pituitary-gonadal function but also hypothalamic-pituitary-adrenal function as well.

Women also experience similar hormonally linked side effects of opioids including depression, dysmenorrhea, sexual dysfunction, and, potentially, reduced bone mineral density. Several studies have demonstrated reduced estrogen levels in women on methadone maintenance (42).

Reduced LH is also observed and appears to be more pronounced in postmenopausal women. Interestingly, testosterone levels also appear to be reduced in women taking prescribed opioids and may be related to body mass index and estrogen replacement therapy (64). The direct consequences of reduced $\mathrm{LH}$ and progesterone levels on dysmenorrhea are currently unclear.

The reductions in estrogen may have implications for osteoporosis and fractures in the older population. Ensrud and colleagues (64) found that, in a cohort of 8,127 older women, patients that were taking opioids had a greater risk for any nonspinal fracture. Some have suggested that, in part, this relative increase in risk of fracture may be due to an androgen-based reduction in bone density (65-67). While this is a plausible hypothesis, there is a lack of causal data connecting the hormonal ef- fects of opioids to reduced bone mineral density. Moreover, while estrogen replacement therapy may be useful in some women to restore menses or maintain bone mineral density in younger women, there have been no controlled studies weighing the benefits of such therapy against the well publicized risks associated with estrogen replacement therapy.

\section{Opioid-induced Hyperalgesia}

Hyperalgesia (also referred to as hyperalgia) is a relatively new recognized adverse effect, and is generally defined as an increased pain sensitivity (68). This sensitization presents as increasing pain despite increasing doses of opioids (69). Long-term use and high doses of opioids may be associated with the development of hyperalgesia, which may be related to opioid metabolites, such as morphine 3-gluceronide (M3G). Opioid-induced cell apoptosis may also be associated with hyperalgesia. The loss of GABA neurons to apoptosis may result in changes in spinal neuronal circuits (70). NMDA receptor agonism also has a major role in the development of hyperalgesia, as does glycine, an inhibitory neurotransmitter that mediates the postsynaptic inhibition of spinal neurons (71). At least in mice, the use of an L-type calcium channel blocker (amlodipine) prevented the hyperalgesia and tolerance of chronic morphine administration (72). This is consistent with the concept that morphine-induced abnormal pain and antinociceptive tolerance may be mediated by enhanced release of excitatory neurotransmitters (73). There are limited treatment options for the hyperalgesia and tolerance; in rats, ketamine (a NMDA antagonist) prevented fentanyl-induced hyperalgesia (74). Recent studies in opioid addicts have helped to confirm the clinical impression that chronic opioid use results in an abnormal pain perception, consistent with hyperalgesia (75).

\section{Opioid-induced Sedation}

The sedating effects of opioids in opioid naïve patients are fairly well known (76). Opioid-induced sedation and drowsiness are thought to be caused by the anticholinergic activity of opioids. Although tolerance to these side effects often develops, dose initiation and rapid dose escalation may result in sedation and consequently lead to noncompliance and/or reduced quality of life. The suggested treatments are opioid dose reduction, opioid rotation, and use of psychosomatic stimulants. 
Psychostimulants may improve psychomotor performance scores and subjective drowsiness (77). Methylphenidate is the most common medication investigated to treat opioid-induced sedation. In a double-blind randomized study of cancer patients receiving continuous subcutaneous opioids, a daily dose of $10 \mathrm{mg}$ methylphenidate significantly improved the mean baseline drowsiness scores by 35\% compared with $8 \%$ in the placebo group (78). In another doubleblind, randomized study in cancer patients, $15 \mathrm{mg}$ of daily methylphenidate use led to a $61 \%$ improvement in drowsiness score, with only $25 \%$ improvement in the placebo group; at the same time, there was an associated decreased pain and decreased number of opioid doses (79). A $15 \mathrm{mg}$ daily dose of methylphenidate was studied in a double-blind randomized fashion in 32 cancer patients maintained on a steady dose of oral opioids (80). The treatment group had a $61 \%$ improvement in drowsiness score, which was significantly greater than $25 \%$ improvement in the placebo group. Methylphenidate was also associated with decreased pain and rescue opioid doses. Multiple uncontrolled studies have also demonstrated positive results with methylphenidate. Although other options like dextroamphetamine, donepezil, modafinil, and caffeine are also available, methylphenidate is the most widely studied agent, and in absence of side effects and abuse potential it should be considered as first line therapy (81).

\section{Opioid-induced Sleep Disturbances}

Sleep disturbance is common in cancer patients (82). It is usually attributed to insomnia or pain, but there is little evidence to support this. Arousal from sleep or disturbed sleep from pain has been reported but there is some evidence that patients in pain do not suffer from disturbed sleep more than those not in pain. In addition, no correlation has been found between pain severity and sleep disturbance. The effect of opioids on sleep in palliative care patients has not been well studied. Opioids are generally believed to enhance sleep but again, there is little evidence to support this belief.

Opioids increase the number of shifts in sleepwaking states (83), and decrease total sleep time, sleep efficiency (84), delta sleep, and REM sleep (85). However, in these studies, it is difficult to differentiate the effects of the opioid medication from the effects of the underlying disorders (e.g., cancer, addiction/dependence, postoperative pain). A study of 7 healthy volunteers treated with IV morphine showed reductions in slow wave sleep and a mild decrease in REM, but no increase in awakenings or arousals (86). A randomized, double-blind study (87) involving 42 healthy volunteers given $5 \mathrm{mg}$ methadone or $15 \mathrm{mg}$ sustained release morphine, showed that both opioids increased the percentage of time spent in light sleep and substantially decreased $(30 \%$ to $50 \%$ ) the percentage of time in deep sleep (stages 3 and 4). No drug effects were seen on sleep efficiency, total sleep time, wake after sleep onset, or subjective measures of mood or fatigue. Both cortical arousal and the sleep-wake cycles are regulated by converging inputs from the brainstem and pontinecholinergic projections (88). Sleep and waking is regulated by many neurotransmitters, including noradrenaline, serotonin, acetylcholine, dopamine, histamine, gamma-aminobutyric acid (GABA), the pituitary hormones, and the neurohormone melatonin. Any drugs that alter the balance of these neurotransmitters, as opioids do, can potentially affect sleep. Although the exact mechanism by which opioids disrupt sleep is unclear, morphine has been shown to reduce REM sleep perhaps in part by modulating GABAergic signaling via inhibition of acetylcholine release in the medial pontine reticular formation. The resultant disruption of sleep architecture affects the states of arousal during wakefulness (89). In animals, REM suppression is associated with mu, but not kappa or delta opioid receptor agonists.

\section{Psychomotor Performance in Opioid THERAPY}

The negative effects of opioids on psychomotor/ driving performance in opioid naïve patients remains controversial in the minds of clinicians - multiple studies support the notion that for many patients it is reasonable to drive on a stable dose of opioids (76,90-92). When opioids are initially added to the management of pain, patients' abilities to operate heavy equipment may be diminished and so they should not be allowed to drive automobiles; however, once a stable opioid analgesic regimen is reached, patients with no significant cognitive/psychomotor impairments should be allowed to drive - as they would be allowed to drive with any medication which can potentially cause central nervous system depression (e.g., antidepressants). In contrast, others believe that patients on stable doses of opioid medications should be allowed to drive vehicles (93). Direct evidence provided in a subset of patients with chronic pain on a stable opioid analgesic regimen (76) 
showed that these patients were capable of operating automobiles safely during daytime, in normal climate weather. A structured, evidence-based review by Fishbain et al (94) suggested that in opioid-dependent/tolerant patients on stable doses of opioids, no impairment of psychomotor abilities are observed even immediately after a dose of opioid.

\section{Opioid-induced Constipation}

Constipation is a common problem, occurring in $40 \%$ to $95 \%$ of patients treated with opioids and can occur even with a single dose of morphine (95). Although often dismissed as a trivial side effect, the long-term consequences of constipation can result in significant morbidity and mortality, with an adverse effect on patient quality of life. Severe constipation can force patients to reduce the dose of the opioid, resulting in decreased analgesia. Chronic constipation can result in hemorrhoid formation, rectal pain and burning, bowel obstruction, and potential bowel rupture and death. Opioids activate mu receptors in the gastrointestinal tract responsible for gut motility (84) from a vascular distribution as well as local application to the gut (96). Reported rates of constipation with spinal administration of opioids vary, but in general it is thought that spinal opioid receptors do not affect intestinal motility and transit in humans $(61,97)$. It is unclear whether opioid-induced constipation in humans is predominantly centrally mediated or peripherally mediated. Morphine may act within the CNS to alter autonomic outflow to the gut (98). Peripherally it affects intestinal motility by a direct stimulation of opioid receptors in the enteric nervous system (99). Loperamide, an opioid receptor agonist with limited ability to cross the blood brain barrier, is used clinically to treat diarrhea, suggesting that opioids have a more direct local constipating effect.

Unlike many of the other side effects of opioids (respiratory depression, nausea, sedation), constipation is unlikely to improve over time, and therefore must be anticipated, monitored, and addressed throughout the opioid treatment course (100) (Table 3). It is suggested that tolerance may be linked to certain subtypes of mu receptors that mediate various pharmacological actions (99). Tolerance develops more readily to mu-1-dependent actions than to nonmu-1-dependent actions. Another hypothesis suggests that development of tolerance requires P-glycoprotein up-regulation. Morphine induces P-glycoprotein up-regulation in the brain, but it does not up-regulate intestinal P-glycoprotein (101).

Assessment of constipation can be difficult; a questionnaire (Patient Assessment of Constipation) that measures symptom severity (PAC-SYM) and quality of life (PAC-QOL) can be used (102). The questionnaire was validated in chronic low back pain patients and found to be a reliable, valid, and responsive measure of the presence and severity of opioid-induced constipation symptoms.

There is a need for effective treatment of opiateinduced constipation. It is partially attenuated by using different types of opioid compounds or routes of administration or combining opioids with other medications. However, refractory constipation may still develop and opioid antagonists may play an important therapeutic role in this respect. Antagonizing the gastrointestinal mu receptors is the basis for many current investigational medications to treat opioid-induced constipation.

A novel approach to management of opioidinduced constipation involves blocking peripheral opioid receptors in the gut with opioid receptor antagonists with prokinetic activity. Two recently developed mureceptor antagonists, methylnaltrexone and alvimopan, are currently under review (103). Methylnaltrexone is a quaternary derivative of naltrexone with strong mureceptor affinity but no intrinsic agonist activity; it blocks the peripheral actions of opioids while sparing central analgesic effects and reverses the gut-slowing action of morphine. It is currently under late-stage clinical investigation for the treatment of opioid-induced constipation in patients with advanced illness. Alvimopan, a selective, competitive mureceptor antagonist with limited oral bioavailability, has been used to reduce the length of postoperative ileus. A systematic review of available data shows proof of concept but does not conclusively demonstrate the efficacy of peripherally acting muopioid antagonists in managing opiate-related constipation (103).

\section{Opioid-induced Bladder Dysfunction}

The risk of opioid-induced bladder dysfunction (i.e., difficulty voiding or frank urinary retention) is a significant problem in postoperative patients, but the incidence has been difficult to estimate because many other factors can play a role. Two studies reported urinary retention in $3.8 \%$ and $18.1 \%$ of patients receiving opioids in the postoperative period $(104,105)$. Urinary 
Table 3. Medications for treatment of chronic constipation.

\begin{tabular}{|c|c|c|c|}
\hline Agent & Formula/strength & Adult dosage & Side effects/complications \\
\hline \multicolumn{4}{|l|}{ Bulk laxatives } \\
\hline $\begin{array}{l}\text { Methylcellulose } \\
\text { (Citrucel) }\end{array}$ & $\begin{array}{l}\text { Powder: } 2 \mathrm{~g} \text { (mix with } 8 \mathrm{oz} \text { liquid) } \\
\text { Tablets: } 500 \mathrm{mg} \text { (take with } 8 \mathrm{oz} \text { liquid) }\end{array}$ & $\begin{array}{l}\text { One to } 3 \text { times } \\
\text { daily } \\
2 \text { tablets up to } 6 \\
\text { times daily }\end{array}$ & $\begin{array}{l}\text { Bulk mass may predispose inactive patients to } \\
\text { obstruction. Most common side effect is increased } \\
\text { intestinal gas. }\end{array}$ \\
\hline $\begin{array}{l}\text { Polycarbophil } \\
\text { (Fibercon) }\end{array}$ & Tablets: $625 \mathrm{mg}$ & $\begin{array}{l}2 \text { tablets } 1 \text { to } 4 \\
\text { times daily }\end{array}$ & $\begin{array}{l}\text { Bulk mass may predispose inactive patients to } \\
\text { obstruction. Most common side effect is increased } \\
\text { intestinal gas. }\end{array}$ \\
\hline Psyllium (Metamucil) & Powder: $3.4 \mathrm{~g}$ (mix with $8 \mathrm{oz}$ liquid) & 1 to 4 times daily & $\begin{array}{l}\text { Bulk mass may predispose inactive patients to } \\
\text { obstruction. Most common side effect is increased } \\
\text { intestinal gas. }\end{array}$ \\
\hline \multicolumn{4}{|l|}{ Stool softeners } \\
\hline $\begin{array}{l}\text { Docusate calcium } \\
\text { (Surfak) }\end{array}$ & Capsules: $240 \mathrm{mg}$ & Once daily & $\begin{array}{l}\text { Ineffective unless adequate fluid intake. Ineffective as } \\
\text { sole agent in patients with decreased bowel motility. } \\
\text { Contra-indicated with mineral oil laxatives. }\end{array}$ \\
\hline $\begin{array}{l}\text { Docusate sodium } \\
\text { (Colace) }\end{array}$ & $\begin{array}{l}\text { Capsules: } 50 \text { or } 100 \mathrm{mg} \\
\text { Liquid: } 150 \mathrm{mg} \text { per } 15 \mathrm{~mL} \\
\text { Syrup: } 60 \mathrm{mg} \text { per } 15 \mathrm{~mL}\end{array}$ & 50 to $300 \mathrm{mg}$ & $\begin{array}{l}\text { Ineffective unless adequate fluid intake. Ineffective as } \\
\text { sole agent in patients with decreased bowel motility. } \\
\text { Contraindicated with mineral oil laxatives. }\end{array}$ \\
\hline \multicolumn{4}{|l|}{ Osmotic laxatives } \\
\hline Lactulose & Liquid: $10 \mathrm{~g}$ per $15 \mathrm{~mL}$ & 15 to $60 \mathrm{~mL}$ daily & $\begin{array}{l}\text { Possible side effects include flatulence, abdominal } \\
\text { cramps, diarrhea, or nausea or vomiting. Use with } \\
\text { caution in diabetics. }\end{array}$ \\
\hline Magnesium citrate & Liquid: $296 \mathrm{~mL}$ per bottle & $\begin{array}{l}0.5 \text { to } 1 \text { bottle per } \\
\text { day }\end{array}$ & $\begin{array}{l}\text { Possible side effects include diarrhea and electrolyte } \\
\text { imbalances. Rarely considered first-line therapy } \\
\text { due to their undesirably strong and quick laxative } \\
\text { activity. Use with caution in patients with decreased } \\
\text { renal function. Excess magnesium can cause CNS } \\
\text { depression, muscle weakness, and EKG changes. }\end{array}$ \\
\hline $\begin{array}{l}\text { Magnesium hydroxide } \\
\text { (Milk of Magnesia) }\end{array}$ & Liquid: $400 \mathrm{mg}$ per $5 \mathrm{~mL}$ & $\begin{array}{l}30 \text { to } 60 \mathrm{~mL} \text { once } \\
\text { daily }\end{array}$ & $\begin{array}{l}\text { Possible side effects include diarrhea and electrolyte } \\
\text { imbalances. Rarely considered first-line therapy } \\
\text { due to their undesirably strong and quick laxative } \\
\text { activity. Use with caution in patients with decreased } \\
\text { renal function. Excess magnesium can cause CNS } \\
\text { depression, muscle weakness, and EKG changes. }\end{array}$ \\
\hline $\begin{array}{l}\text { Polyethylene glycol } \\
3350 \text { (Miralax) }\end{array}$ & Powder: $17 \mathrm{~g}$ (mix with $8 \mathrm{oz}$ liquid) & Once daily & $\begin{array}{l}\text { Side effects include abdominal pain, bloating, } \\
\text { cramping, and increased intestinal gas. More severe } \\
\text { side effects include diarrhea and hives. }\end{array}$ \\
\hline $\begin{array}{l}\text { Sodium biphosphate } \\
\text { (Phospho-Soda) }\end{array}$ & $\begin{array}{l}\text { Liquid: } 45 \mathrm{~mL}, 90 \mathrm{~mL} \text { (mix with } 4 \mathrm{oz} \\
\text { water, then follow with } 8 \mathrm{oz} \text { water) }\end{array}$ & 20 to $45 \mathrm{~mL}$ daily & $\begin{array}{l}\text { Use with caution in patients on sodium restricted } \\
\text { diets. Use with caution in patients with decreased } \\
\text { renal function. }\end{array}$ \\
\hline Sorbitol & Liquid: $480 \mathrm{~mL}$ & 30 to $150 \mathrm{~mL}$ daily & $\begin{array}{l}\text { Side effects may include nausea, gas, diarrhea, } \\
\text { stomach cramps, or anal irritation. }\end{array}$ \\
\hline \multicolumn{4}{|l|}{ Stimulant laxatives } \\
\hline Bisacodyl (Dulcolax) & Tablets: $5 \mathrm{mg}$ & 5 to $15 \mathrm{mg}$ daily & $\begin{array}{l}\text { Side effects may include stomach ache, cramping, } \\
\text { weakness, sweating, irritation of the rectal area, } \\
\text { diarrhea, or dizziness. Do not use in presence of } \\
\text { nausea, vomiting, or other symptoms of bowel } \\
\text { obstruction. }\end{array}$ \\
\hline
\end{tabular}


Table 3. Continued.

\begin{tabular}{|c|c|c|c|}
\hline Agent & Formula/strength & Adult dosage & Side effects/complications \\
\hline Cascara sagrada & $\begin{array}{l}\text { Liquid: } 120 \mathrm{~mL} \\
\text { Tablets: } 325 \mathrm{mg}\end{array}$ & $\begin{array}{l}5 \mathrm{~mL} \text { once daily } \\
1 \text { tablet daily }\end{array}$ & $\begin{array}{l}\text { Side effects may include strong cramping in the } \\
\text { abdomen, electrolyte imbalance (loss of potassium), } \\
\text { loss of body fluids, and dark pigmentation in the } \\
\text { colon, called melanosis coli. Long-term use has been } \\
\text { linked to the development of colorectal growths } \\
\text { (adenomas) and cancer. Interaction may occur with } \\
\text { cardiac glycosides, such as digitalis. Do not use in } \\
\text { presence of nausea, vomiting, or other symptoms of } \\
\text { bowel obstruction. }\end{array}$ \\
\hline Castor oil & Liquid: $60 \mathrm{~mL}$ & $\begin{array}{l}15 \text { to } 60 \mathrm{~mL} \text { once } \\
\text { daily }\end{array}$ & $\begin{array}{l}\text { Side effects can include abdominal pain or cramping, } \\
\text { colic, nausea, vomiting, and diarrhea. Long-term } \\
\text { use of castor oil can lead to fluid and electrolyte loss. } \\
\text { Do not use in presence of nausea, vomiting, or other } \\
\text { symptoms of bowel obstruction. Contraindicated in } \\
\text { pregnancy or during breastfeeding. }\end{array}$ \\
\hline Senna (Senokot) & Tablets: $8.6 \mathrm{mg}$ & $\begin{array}{l}2 \text { or } 4 \text { tablets once } \\
\text { or twice daily }\end{array}$ & $\begin{array}{l}\text { Side effects may include strong cramping and } \\
\text { abdominal pain, electrolyte imbalance (loss of } \\
\text { potassium), loss of body fluids, nausea, rash, swelling } \\
\text { of the fingertips, weight loss, and dark pigmentation } \\
\text { in the colon, called melanosis coli. Long-term use has } \\
\text { been linked to the development of colorectal growths } \\
\text { (adenomas) and cancer. May interact with calcium } \\
\text { channel blockers and Indocin. It has been linked to } \\
\text { liver toxicity. }\end{array}$ \\
\hline \multicolumn{4}{|l|}{ Prokinetic Agents } \\
\hline Tegaserod (Zelnorm) & Tablets: $2 \mathrm{mg}, 6 \mathrm{mg}$ & 2 times daily $\ddagger$ & $\begin{array}{l}\text { In March 2007, the FDA asked Novartis to stop sales } \\
\text { of Zelnorm in the U.S. effective immediately. The } \\
\text { FDA's action was the result of a new analysis of } 29 \\
\text { clinical studies of Zelnorm that showed an increased } \\
\text { risk of heart attack, stroke, and angina (chest pain) } \\
\text { in patients who took Zelnorm. Side effects include } \\
\text { headache, abdominal pain, and diarrhea. Other } \\
\text { side effects include rectal bleeding, bloody diarrhea, } \\
\text { or new or worsening abdominal pain that may be } \\
\text { symptoms of intestinal ischemia. }\end{array}$ \\
\hline
\end{tabular}

retention is much more likely to occur after epidural injection of morphine rather than intravenous or intramuscular injection (106). The mechanism of urinary retention is still not completely understood. Opioids are well known to decrease detrusor tone and the force of contraction, decrease the sensation of fullness and urge to void, and inhibit the voiding reflex. They probably do not increase sphincter tone (107). These effects are naloxone reversible. Animal and human studies suggest a significant centrally mediated effect on the brain and spinal cord, although peripheral effects at the bladder may also play a role. Rosow and colleagues (108) demonstrated that opioid-induced changes in bladder function are due, in part, to a peripheral opioid effect and can be reversed by methylnaltrexone, a peripheral opioid antagonist indicating that peripheral mechanisms may play a role.

\section{Cardiac Effects of Opioids}

The cardiac side effects of opioids are not very common. Morphine has been associated with histamine release and consequent vasodilation and hypotension (109). This adverse effect is partially blocked by $\mathrm{H} 1$ antagonism but completely reversed by naloxone. Parasympathetic stimulation may also contribute to bradycardia. Recently, a syndrome of QT prolongation and torsade des pointes ( $\mathrm{Tdp}$ ) has drawn some attention partially due to an increase in use of methadone for treatment of chronic pain $(110,111)$. Mortality rate due to Tdp could be as much as $17 \%$ (112) and therefore it is prudent to monitor the EKG for presence of QT prolongation in patients receiving methadone.

Methadone can block the human ether-a-go-gorelated-gene (hERG) channel causing QT prolongation and torsades de pointes ventricular tachycardia (113- 
115). The incidence of tachycardia-corrected QT prolongation (QTc) of greater than 500 milliseconds was found to be $16 \%$ among heroin addicts treated with methadone, and TdP occurred in $3.6 \%$ of that same group (116). The absolute QTc value of 500 ms has been known as a definite risk factor to develop Tdp. But, some have suggested that a QT prolongation of more than $30 \mathrm{~ms}$ from the baseline should be considered clinically significant, and more than $60 \mathrm{~ms}$ prolongation beyond baseline is a risk factor to develop $\operatorname{Tdp}(117,118)$. The QTC prolongation by methadone has been attributed to its (R)-enantiomer which has 50 times more analgesic potency than its (S)-enantiomer (119). Clinically significant QTc prolongation has been mostly observed in patients taking total daily doses of more than $40 \mathrm{mg}$ methadone (120). But in a recent retrospective review, lower daily doses of $30 \mathrm{mg}$ methadone were found to cause QTc prolongation, and Tdp was observed in patients receiving daily doses of 40-200 mg methadone. Significant correlation was observed between QTc prolongation and patients receiving methadone and CYP3A4 inhibitors like fluoxetine, clarithromycin, fluconazole, and valproate (116). The same report also identified hypokalemia and diminished liver function as other risk factors for developing QTc prolongation. Previously in separate reports, other medications like cocaine, tricyclic antidepressants, quinine, haloperidol, droperidol, chlorpromazine, and erythromycin had been implicated to cause QTc prolongation (Table 4). An updated list of medications causing Tdp-VT can be found at www.qtdrugs.org.

The serious consequence of QTC prolongation has prompted some to recommend repeated surface EKGs during the course of treatment with methadone, especially when raising the dose and adding other medications like CYP3A4 inhibitors and also when hypokalemia and diminished liver function are present (121).

Table 4. Factors correlated with QT prolongation in methadone use.

- CYP3A4 inhibitors (e.g. fluoxetine, clarithromycin, fluconazole and valproate)

- Hypokalemia

- Diminished liver function

- Cocaine

- Tricyclic antidepressants

- Haloperidol

- Droperidol

\section{Adverse Effects of Specific Opioids}

This section explores both common and uncommon specific complications of the administration of several medications including codeine, hydrocodone, hydromorphone, oxycodone, oxymorphone, morphine, and fentanyl.

Codeine is commonly used in the postpartum period for pain associated with episiotomy and cesarean section. As most mothers initiate breastfeeding, the safety of codeine and its pharmacologically active metabolite, morphine, amongst breastfed infants is of primary concern. The American Academy of Pediatrics lists codeine as compatible with breastfeeding. However, Koren et al (83) published a case of a full-term, breastfed infant who died in a manner consistent with morphine overdose. An explanation proposed was that if the mother is an ultrarapid metabolizer of cytochrome P450 2D6, she produces much more morphine when taking codeine than most people do. Options to reduce the risk include discontinuing codeine after 2 -3 days of use and being aware of symptoms of potential opioid toxicity in both mothers and newborns.

Hydrocodone/acetaminophen is one of the most commonly prescribed medications for both acute and chronic pain relief in the United States, and is effective as both an antitussive and opioid analgesic. Common adverse reactions to this medication combination include dizziness, nausea, vomiting, drowsiness, and euphoria. Respiratory depression and mood disturbance are rare. As with all opioids, hydrocodone may lead to physical and psychological dependence. Hearing loss is an infrequently recognized side effect of hydrocodone use, with only a few case reports to date. Friedman et al (122) described 12 patients with profound hearing loss attributed to hydrocodone (4 were initially unilateral); none noted relief after high dose steroids, and 7 of the 8 who underwent cochlear implantation had good early response. Ho et al (123) described the clinical characteristics of 5 patients who presented with progressive sensorineural hearing loss, suspected to be due to chronic hydrocodone/acetaminophen use. The admitted hydrocodone dose ranged from 10 to $300 \mathrm{mg}$ per day. None responded to high dose steroids, and all responded to cochlear implant. The authors felt that genetic polymorphisms of the drug metabolizing enzymes CYP2D6 or CYP3D4 or associated comorbidities such as hepatitis $C$ may predispose certain individuals to adverse reactions to the drug. It is unclear whether the hearing loss is due to the hydrocodone or the associated acetaminophen. 
OROS hydromorphone is a controlled-release formulation that uses an active osmotic system to deliver consistent levels of hydromorphone over 24 hours and achieve rapid steady state concentrations. Wallace at el (124) investigated the safety and efficacy of once-daily OROS hydromorphone in patients with moderate-tosevere chronic low back pain. The study involved 209 patients randomized to receive treatment in 15 North American study centers. The most common side effects included constipation (20.9\%), nausea (19.8\%), vomiting $(9.7 \%)$, headache $(14.0 \%)$, and somnolence $(14.0 \%)$. Long-acting opioids usually cause similar adverse event profiles to short-acting agents, with the most frequent effects on the gastrointestinal and nervous systems.

Oxymorphone is an opioid specific for the mu receptor and is approved to treat both acute and chronic pain. Chamberlin et al (125) described the pharmacology, safety, efficacy, and usage of oral oxymorphone for pain management. Unlike oxycodone, it does not bind the kappa opioid receptor. This medication undergoes extensive hepatic metabolism and it is contraindicated in patients with moderate to severe liver impairment. However, there is no report of significant CYP3A4, 2C9, or 2D6 drug interactions. The absence of CYP2D6 metabolism limits its potential to cause some of the more common drug interactions via the CYP450 system. The elderly can experience a $40 \%$ increase in plasma concentrations while renally impaired patients may have a $57-65 \%$ increase in bioavailability. Food can also increase the rate of absorption by as much as $50 \%$, necessitating dosing either 1 hour before or 2 hours after a meal. Primary adverse side effects include nausea, vomiting, pruritus, pyrexia, and constipation. Notably, the manufacturer lists nausea and pyrexia as the most common (defined as $>10 \%$ ). Caution is also warranted with using oxymorphone with other CNS depressants including opioids, general anesthetics, antidepressants, phenothiazines, sedatives, and hypnotics. The manufacturer also warns of confusion, disorientation, respiratory depression, apnea, and seizures when oxymorphone is given with cimetidine. However, no cause and effect relationship is known or given for this warning. Mixed agonist/antagonist analgesics (e.g., butorphanol, buprenorphine) can also reduce the medication's efficacy and precipitate withdrawal symptoms in patients who take oxymorphone. Respiratory depression is also a concern and the medication is prescribed with caution in patients with hypoxia, hypercapnia, or decreased respiratory reserve.
Further, this medication may aggravate seizures in patients with seizure disorders, as all opioids can potentially lower the seizure threshold. Additionally, since opioids may cause sphincter of Oddi spasm, plasma amylase and lipase levels may unexpectedly increase. Caution is warranted in patients with biliary tract disease such as acute pancreatitis or cholelithiasis.

Oxycodone CR is a long-acting opioid used for the treatment of noncancer pain. Portenoy et al (126) performed an open-label, uncontrolled, prospective longitudinal investigation of outcomes associated with use of Oxycodone CR. The study provides evidence that the greatest need for dose titration occurs during the first 3 months for most patients, after which further dose escalation is minimal. During the 3 year study, the most common adverse events included constipation $(15 \%)$ and nausea (12\%). Other adverse events included somnolence $(8 \%)$, vomiting $(7 \%)$, and depression ( $2 \%)$. After the first 3 months, the incidence of all the common adverse events except depression declined substantially. The most serious adverse events included chest pain and accidental injury. All patients with chest pain had cardiac risk factors at the time of study entry and the accidental injuries reported were mostly fractures.

Morphine is used for the treatment of noncancer pain. Osteoarthritis is often treated with opioids as NSAIDS may cause gastrointestinal injury as well as renal compromise. The efficacy and safety of several branded sustained release morphine medications has been studied in randomized trials to be comparable to generic sustained release morphine (127). Constipation is one of the primary reasons for adverse event related patient withdrawal in this study.

Fentanyl is also used for the treatment of chronic low back pain. The delivery systems include transdermal, buccal tablet, and oral transmucosal preparations. Allan et al (128) studied the use of transdermal fentanyl (TDF) in strong opioid naïve patients with chronic low back pain in an open, randomized, parallel group multicenter study. This study looked at the efficacy and safety of TDF and sustained release morphine (SRM) in strong opioid naïve patients with chronic low back pain. Data from 680 patients studied over 13 months showed similar pain relief with both medications but TDF caused significantly less constipation. Another study by Portenoy et al (129) studied the fentanyl buccal tablet (FBT) for relief of breakthrough pain in opioid-treated patients with chronic low back pain with a randomized, placebo-controlled study. 
FBT is a new formulation of fentanyl that enhances transbuccal drug delivery via an effervescent reaction. Currently it is FDA approved for cancer related breakthrough pain. Adverse events were reported in $65 \%$ of patients including nausea (19\%), dizziness (13\%), somnolence $(9 \%)$, dysgeusia $(8 \%)$, vomiting $(6 \%)$, and dry mouth (5\%). Two patients experienced serious adverse events during the study including diabetic gastroparesis and accidental overdose resulting in loss of consciousness. This patient took 4 of the 600 mcg tablets without explanation. He fully recovered after resuscitation with oxygen and admission to the hospital. This is an untoward opioid-related effect, which may make this medication seem less attractive for breakthrough back pain. The study did show FBT is generally well tolerated at doses of $100-800 \mathrm{mcg}$ and provides evidence that a rapid-onset opioid is useful for pain not associated with cancer.

\section{Discussion}

Adverse events related to the opioids discussed above appear similar except for a few exceptions. In general, they appear to fall into 2 broad categories: nonlife-threatening and life-threatening. Hydrocodone may cause sensorineural hearing loss due to possible genetic polymorphisms. Constipation and nausea are the most common adverse effects and also lead to dropouts in controlled trials. Both constipation and nausea occurred more often with opioid therapy compared to treatment with tricyclic antidepressants in the only study that compared these 2 treatments with placebo in postherpetic neuralgia (130). Dellemijn et al (131) reported high incidence of sweating, anorexia, and clouded vision. Their study also assessed the severity of adverse effects and found that the mean intensity of adverse effects, particularly that of sedation, decreased gradually over 2 - 3 months. Tolerance may not develop to the constipating effects of opioids, and so constipation should be treated early and effectively. Two RCTs on oral opioids $(132,133)$ reported withdrawal symptoms that occurred in $1-2 \%$ of patients. After the treatment period, drug craving was reported by $8.7 \%$ of patients on morphine compared with $4.3 \%$ on placebo (134). The Cochrane review of opioids for neuropathic pain (135) reported a majority of adverse events and withdrawals from 8 intermediate term placebo controlled trials $(130,136-141)$. Analysis of 4 studies reviewed by the authors of the Cochrane review $(136,137,139,141)$ revealed that $23(11 \%)$ of 212 patients withdrew because of adverse events during opioid therapy versus 9 (4\%) of 202 receiving placebo. Another study (142) reported adverse events on a VAS, precluding determination of the numbers of affected participants. The most common adverse events were nausea (33\% opioid versus $9 \%$ control) and constipation (33\% opioid versus $10 \%$ control), followed by drowsiness ( $29 \%$ opioid versus $6 \%$ control), and vomiting ( $15 \%$ opioid versus $3 \%$ control).

With all opioids, respiratory depression and death are the most feared complications. From 1979 to 1990, unintentional drug poisoning death rates were on average $5.3 \%$ per year; however, from 1990 to 2002, the rate increased to $18.1 \%$ per year. In that same time period, the number of opioid analgesic poisonings on death certificates increased $91.2 \%$, while heroin deaths increased only $12.4 \%$ and cocaine deaths $22.8 \%$. The increase in deaths generally matched the increase in sales for each type of opioid.

Drug deaths from opioids are a serious and increasing issue. Effective patient compliance with appropriate medical treatment programs are needed to prevent rare but life-threatening adverse events.

\section{Conclusion}

There is evidence that opioid medications can be effective in treating a variety of chronic pain conditions but, like most pharmaceutical based therapies, their use can be potentially accompanied by side effects and complications. Despite the rise in serious adverse events involving the use of opioids, including death, these medications continue to be widely prescribed in the majority of patients suffering from chronic pain. Proper prescribing practices as well as physician and patient education can help manage tolerance issues, adverse events, as well as common and uncommon side effects. 


\section{References}

1. Aragon-Poce F, Martinez-Fernandez E, Marquez-Espinos C, Perez A, Mora R, Torres LM. History of opium. International Congress Series 2002; 1242:1921.

2. Goodrich JT. History of spine surgery in the ancient and medieval worlds. Neurosurg Focus 2004; 16: E2.

3. Trescot AM, Boswell MV, Atluri SL, Hansen HC, Deer TR, Abdi S, Jasper JF, Singh $V$, Jordan $A E$, Johnson BW, Cicala RS, Dunbar EE, Helm II S, Varley KG, Suchdev PK, Swicegood JR, Calodney AK, Ogoke BA, Minore WS, Manchikanti L. Opioid guidelines in the management of chronic non-cancer pain. Pain Physician 2006; 9:1-40.

4. Manchikanti L, Whitfield E, Pallone F. Evolution of the National All Schedules Prescription Electronic Reporting Act (NASPER): A public law for balancing treatment of pain and drug abuse and diversion. Pain Physician 2005; 8:335347.

5. Manchikanti L. Prescription drug abuse: What is being done to address this new drug epidemic? Testimony before the Subcommittee on Criminal Justice, Drug Policy, and Human Resources. Pain Physician 2006; 9:287-321.

6. Manchikanti L. National drug control policy and prescription drug abuse: Facts and fallacies. Pain Physician 2007; 10:399-424.

7. Gajraj N, Hervias-Sanz M. Opiate abuse or undertreatment? Clin J Pain 1998; 14:90-91.

8. Simon S, Bennett D, Rauck R, Taylor D, Shoemaker S. Prevalence and characteristics of breakthrough pain in noncancer patients with chronic neuropathic pain. Pain Med 2005; 6:192.

9. Bennett D, Simon S, Rauck R, Taylor D, Shoemaker S. Prevalence and characteristics of breakthrough pain in noncancer patients with chronic back pain. Pain Med 2005; 6:193.

10. Fishbain DA, Rosomoff HL, Rosomoff RS. Drug abuse, dependence, and addiction in chronic pain patients. Clin J Pain 1992; 8:77-85.

11. Chabal C, Erjavec MK, Jacobson L, Mariano A, Chaney E. Prescription opiate abuse in chronic pain patients: Clinical criteria, incidence, and predictors. Clin J Pain 1997; 13:150-155.

12. Katz NP, Sherburne S, Beach M, Rose RJ, Vielguth J, Bradley J, Fanciullo GJ. Behavioral monitoring and urine toxicology testing in patients receiving long-term opioid therapy. Anesth Analg 2003; 97:1097-1102.

13. Kell M. Monitoring compliance with Oxy-Contin prescriptions in 14,712 patients treated in 127 outpatient pain centers. Pain Med 2005; 6:186-187.

14. Chou R, Clark E, Helfand M. Comparative efficacy and safety of long-acting oral opioids for chronic non-cancer pain: A systematic review. J Pain Symptom Manage 2003; 26:1026-1048.

15. Kalso E, Edwards JE, Moore RA, McQuay HJ. Opioids in chronic non-cancer pain: Systematic review of efficacy and safety. Pain 2004; 112:372-380.

16. Von Korff M, Deyo RA. Potent opioids for chronic musculoskeletal pain: Flying blind? Pain 2004; 109:207-209.

17. Breivik H. Opioids in chronic non-cancer pain, indications and controversies. EurJ Pain 2005; 9:127-130.

18. Luo X, Pietrobon R, Hey L. Patterns and trends in opioid use among individuals with back pain in the United States. Spine 2004; 29:884-891.

19. Caudill-Slosberg MA, Schwartz LM, Woloshin S. Office visits and analgesic prescriptions for musculoskeletal pain in US: 1980 vs. 2000. Pain 2004; 109:514-519.

20. Manchikanti L, Cash KA, Damron KS, Manchukonda R, Pampati V, McManus CD. Controlled substance abuse and illicit drug use in chronic pain patients: An evaluation of multiple variables. Pain Physician 2006; 9:215-225.

21. Manchikanti L, Pampati V, Damron KS, Brandon DE, Cash KA, McManus CD. Does random urine drug screening reduce illicit drug use in chroic pain patients receiving opioids? Pain Physician 2006; 9:123-129.

22. Manchikanti KN, Manchikanti L, Damron KS, Pampati V, Fellows B. Death from psychotherapeutic agents: An evaluation in interventional pain management practice. In submission; 2008.

23. Manchikanti L, Damron KS, McManus CD, Barnhill RC. Patterns of illicit drug use and opioid abuse in patients with chronic pain at initial evaluation: A prospective, observational study. Pain Physician 2004; 7:431-437.

24. Manchikanti L, Pampati V, Damron KS, Beyer CD, Barnhill RC, Fellows B. Prevalence of prescription drug abuse and dependency in patients with chronic pain in western Kentucky. J KY Med Assoc 2003; 101:511-517.

25. Manchikanti L, Damron KS, Pampati V,
McManus CD. Prevalence of illicit drug use among individuals with chronic pain in the Commonwealth of Kentucky: An evaluation of patterns and trends. J Ky Med Assoc 2005; 103:55-62.

26. Manchikanti L, Damron KS, Beyer CD, Pampati V. A comparative evaluation of illicit drug use in patients with or without controlled substance abuse in interventional pain management. Pain Physician 2003; 6:281-285.

27. Manchikanti L, Damron KS, Mcmanus CD. Patterns of illicit drug use and opioid abuse in patients with chronic pain at initial evaluation: A prospective, observational study. Pain Physician 2004; 7:431-437.

28. Substance Abuse and Mental Health Services Administration (2006). Results from the 2005 National Survey on Drug Use and Health: National Findings. (Office of Applied Studies, NSDUH Series H-30, DHHS Publication No. SMA 064194). Rockville, MD. www.oas.samh sa.gov/nsduh/2k5nsduh/2k5Results. pdf.

29. Collett BJ. Opioid tolerance: The clinical perspective. Br J Anaesth 1998; 81:5868.

30. Cepeda-Benito A, Davis KW, Harraid JH. Associative and behavioral tolerance to the analgesic effects of nicotine in rats: Tail flick and paw-lick assays. Psychopharmacology (Berl) 2005; 180:224233.

31. Light AB, Torrance EG. Opiate addiction. VI: The effects of abrupt withdrawal followed by readministration of morphine in human addicts, with special reference to the composition of the blood, the circulation and the metabolism. Arch Intern Med 1929; 44:1-16.

32. Ballantyne JC. Opioids for chronic pain: Taking stock. Pain 2006; 125:3-4.

33. Trang T, Quirion R, Jhamandas K. The spinal basis of opioid tolerance and physical dependence: Involvement of calcitonin gene-related peptide, substance $p$, and arachidonic acid-derived metabolites. Peptides 2005; 26:13461355.

34. Athanasos P, Smith CS, White JM, Somogyi AA, Bochner F, Ling W. Methadone maintenance patients are crosstolerant to the antinociceptive effects of very high plasma morphine concentrations. Pain 2006; 120:267-275.

35. Stephanou A, Fitzharris P, Knight RA, Lightman SL. Characteristics and kinetics of proopiomelanocortin mRNA ex- 
pression by human leucocytes. Brain Behav Immun 1991; 5:319-327.

36. Peterson PK, Molitor TW, Chao CC. The opioid-cytokine connection. J Neuroimmunol 1998; 83:63-69.

37. Chuang TK, Killam KF Jr, Chuang LF, Kung HF, Sheng WS, Chao CC, Yu L, Chuang RY. Mu opioid receptor gene expression in immune cells. Biochem Biophys Res Commun 1995; 216:922-930.

38. Radulovic J, Jankovic BD. Opposing activities of brain opioid receptors in the regulation of humoral and cell-mediated immune responses in the rat. Brain Res 1994; 661:189-195.

39. Dimitrijevic M, Stanojevic S, Kovacevic-Jovanovic V, Miletic T, Vujic-Redzic V, Radulovic J. Modulation of humoral immune responses in the rat by centrally applied met-enk and opioid receptor antagonists: Functional interactions of brain $\mathrm{OP}_{1}, \mathrm{OP}_{2}$ and $\mathrm{OP}_{3}$ receptors. $/ \mathrm{m}$ munopharmacology 2000; 49:255-262.

40. Pacifici R, Patrini G, Venier I, Parolaro $D$, Zuccaro P, Gori E. Effect of morphine and methadone acute treatment on immunological activity in mice: Pharmacokinetic and pharmacodynamic correlates. I Pharmacol Exp Ther 1994; 269:1112-1116.

41. Daniell HW. Hypogonadism in men consuming sustained-action oral opioids. J Pain 2002; 3:377-384.

42. Daniell HW. Opioid endocrinopathy in women consuming prescribed sustained-action opioids for control of nonmalignant pain. J Pain 2008; 9:2836.

43. Daniell HW. DHEAS deficiency during consumption of sustained-action prescribed opioids: Evidence for opioid-induced inhibition of adrenal androgen production. J Pain 2006; 7:901-907.

44. Daniell HW, Lentz R, Mazer NA. Openlabel pilot study of testosterone patch therapy in men with opioid-induced androgen deficiency. J Pain 2006; 7:200210.

45. Facchinetti F, Comitini G, Petraglia F, Volpe A, Genazzani AR. Reduced estriol and dehydroepiandrosterone sulphate plasma levels in methadone-addicted pregnant women. Eur J Obstet Gynecol Reprod Biol 1986; 23:67-73.

46. Rajagopal A, Vassilopoulou-Sellin R, Palmer JL, Kaur G, Bruera E. Hypogonadism and sexual dysfunction in male cancer survivors receiving chronic opioid therapy. I Pain Symptom Manage 2003; 26:1055-1061.

47. Bliesener N, Albrecht S, Schwager A,
Weckbecker K, Lichtermann D, Klingmuller D. Plasma testosterone and sexual function in men receiving buprenorphine maintenance for opioid dependence. I Clin Endocrinol Metab 2005; 90:203-206.

48. Oltmanns KM, Fehm HL, Peters A. Chronic fentanyl application induces adrenocortical insufficiency. J Intern Med 2005; 257:478-480.

49. Facchinetti F, Volpe A, Farci G, Petraglia F, Porro CA, Barbieri G, Cioni A, Balestrieri A, Genazzani AR. Hypothalamus-pituitary-adrenal axis of heroin addicts. Drug Alcohol Depend 1985; 15:361-366.

50. Hemmings R, Fox G, Tolis G. Effect of morphine on the hypothalamic-pituitary axis in postmenopausal women. Fertil Steril 1982; 37:389-391.

51. Petraglia F, Porro C, Facchinetti F, Cicoli C, Bertellini E, Volpe A, Barbieri GC, Genazzani AR. Opioid control of LH secretion in humans: Menstrual cycle, menopause and aging reduce effect of naloxone but not of morphine. Life Sci 1986; 38:2103-2110.

52. Raff H, Norton AJ, Flemma RJ, Findling JW. Inhibition of the adrenocorticotropin response to surgery in humans: Interaction between dexamethasone and fentanyl. J Clin Endocrinol Metab 1987; 65:295-298.

53. Abs R, Verhelst J, Maeyaert J, Van Buyten JP, Opsomer F, Adriaensen H, Verlooy J, Van Havenbergh T, Smet M, Van Acker K. Endocrine consequences of long-term intrathecal administration of opioids. J Clin Endocrinol Metab 2000; 85:2215-2222.

54. Paice JA, Penn RD, Ryan WG. Altered sexual function and decreased testosterone in patients receiving intraspinal opioids. J Pain Symptom Manage 1994; 9:126-131.

55. Mendelson JH, Mello NK. Plasma testosterone levels during chronic heroin use and protracted abstinence. A study of Hong Kong addicts. Clin Pharmacol Ther 1975; 17:529-533.

56. Mendelson JH, Meyer RE, Ellingboe J, Mirin SM, McDougle M. Effects of heroin and methadone on plasma cortisol and testosterone. J Pharmacol Exp Ther 1975; 195:296-302.

57. Delitala G, Grossman A, Besser GM. The participation of hypothalamic dopamine in morphine-induced prolactin release in man. Clin Endocrinol (Oxf) 1983; 19:437-444.

58. Vermeulen A, Deslypere JP, Kaufman JM. Influence of antiopioids on luteinizing hormone pulsatility in aging men. J Clin Endocrinol Metab 1989; 68:68-72.

59. Hall GM, Lacoumenta S, Hart GR, Burrin JM. Site of action of fentanyl in inhibiting the pituitary-adrenal response to surgery in man. Br J Anaesth 1990; 65:251-253.

6o. Brown RT, Zuelsdorff M, Fleming M. Adverse effects and cognitive function among primary care patients taking opioids for chronic nonmalignant pain. J Opioid Manag 2006; 2:137-146.

61. Ruan X. Drug-related side effects of long-term intrathecal morphine therapy. Pain Physician 2007; 10:357-366.

62. Woody G, McLellan AT, O’Brien C, Persky H, Stevens G, Arndt I, Carroff S. Hormone secretion in methadone-dependent and abstinent patients. NIDA Res Monogr 1988; 81:216-223.

63. Hallinan R, Byrne A, Agho K, McMahon C, Tynan P, Attia J. Erectile dysfunction in men receiving methadone and buprenorphine maintenance treatment. / Sex Med 2007; Dec 18. [Epub ahead of print].

64. Ensrud KE, Blackwell T, Mangione CM, Bowman PJ, Bauer DC, Schwartz A, Hanlon JT, Nevitt MC, Whooley MA. Study of Osteoporotic Fracture Research Group. Central nervous system active medications and risk for fractures in older women. Arch Intern Med 2003; 163:949-957.

65. Daniell HW. Opioid osteoporosis. Arch Intern Med 2004; 164:338.

66. Kim TW, Alford DP, Malabanan A, Holick MF, Samet JH. Low bone density in patients receiving methadone maintenance treatment. Drug Alcohol Depend 2006; 85:258-262.

67. Pedrazzoni M, Vescovi PP, Maninetti L, Michelini M, Zaniboni G, Pioli G, Costi D, Alfano FS, Passeri M. Effects of chronic heroin abuse on bone and mineral metabolism. Acta endocrinol (Copenh) 1993; 129:42-45.

68. Mercadante S, Villari P, Ferrera P. Burst ketamine to reverse opioid tolerance in cancer pain. J Pain Symptom Manage 2003; 25:302-305.

69. Mercadante S, Arcuri E. Hyperalgesia and opioid switching. Am J Hosp Palliat Care 2005; 22:291-294.

70. Mao J, Sung B, Ji RR, Lim G. Neuronal apoptosis associated with morphine tolerance: Evidence for an opioid-induced neurotoxic mechanism. J Neurosci 2002; 22:7650-7661.

71. Mercadante S, Ferrera P, Villari P, Arcuri E. Hyperalgesia: An emerging iatrogen- 
ic syndrome. J Pain Symptom Manage 2003; 26:769-775.

72. Dogrul A, Bilsky EJ, Ossipov MH, Lai J, Porreca F. Spinal L-type calcium channel blockade abolishes opioid-induced sensory hypersensitivity and antinociceptive tolerance. Anesth Analg 2005; 101:1730-1735.

73. Mao J, Price DD, Mayer DJ. Mechanisms of hyperalgesia and morphine tolerance: A current view of their possible interactions. Pain 1995; 62:259-274.

74. Van Elstraete AC, Sitbon P, Trabold F, Mazoit JX, Benhamou D. A single dose of intrathecal morphine in rats induces long-lasting hyperalgesia: The protective effect of prior administration of ketamine. Anesth Analg 2005; 101:1750-1756.

75. Pud D, Cohen D, Lawental E, Eisenberg E. Opioids and abnormal pain perception: New evidence from a study of chronic opioid addicts and healthy subjects. Drug Alcohol Depend 2006; 82:218-223.

76. Byas-Smith MG, Chapman SL, Reed B, Cotsonis $G$. The effect of opioids on driving and psychomotor performance in patients with chronic pain. Clin J Pain 2005; 21:345-352.

77. Ahmedzai S. New approaches to pain control in patients with cancer. Eur J Cancer 1997; 33:S8-14.

78. Bruera E, Miller MJ, Macmillan K, Kuehn N. Neuropsychological effects of methylphenidate in patients receiving a continuous infusion of narcotics for cancer pain. Pain 1992; 48:163-166.

79. Wilwerding MB, Loprinzi CL, Mailliard JA, O'Fallon JR, Miser AW, van Haelst C, Barton DL, Foley JF, Athmann LM. A randomized, crossover evaluation of methylphenidate in cancer patients receiving strong narcotics. Support Care Cancer 1995; 3:135-138.

80. Bruera E, Chadwick S, Brenneis C, Hanson J, MacDonald RN. Methylphenidate associated with narcotics for the treatment of cancer pain. Cancer Treat Rep 1987; 71:67-70.

81. Reissig JE, Rybarczyk AM. Pharmacologic treatment of opioid-induced sedation in chronic pain. Ann Pharmacother 2005; 39:727-731.

82. Moore P, Dimsdale JE. Opioids, sleep, and cancer-related fatigue. Med Hypotheses 2002; 58:77-82.

83. Koren G, Cairns J, Chitayat D, Gaedigk A, Leeder SJ. Pharmacogenetics of morphine poisoning in a breastfed neonate of a codeine-prescribed mother. Lancet
2000; 368:704.

84. Kurz A, Sessler DI. Opioid-induced bowel dysfunction: Pathophysiology and potential new therapies. Drugs 2003; 63:649-671.

85. Pickworth WB, Neidert GL, Kay DC. Morphinelike arousal by methadone during sleep. Clin Pharmacol Ther 1981; 30:796-804.

86. Shaw IR, Lavigne G, Mayer P, Choiniere $M$. Acute intravenous administration of morphine perturbs sleep architecture in healthy pain-free young adults: A preliminary study. Sleep 2005; 28:677682.

87. Dimsdale JE, Norman D, DeJardin D, Wallace MS. The effect of opioids on sleep architecture. J Clin Sleep Med 2007; 3:33-36.

88. Vella-Brincat J, Macleod AD. Adverse effects of opioids on the central nervous systems of palliative care patients. J Pain Palliat Care Pharmacother 2007; 21:15-25.

89. Slatkin N, Rhiner M. Treatment of opioid-induced delirium with acetylcholinesterase inhibitors: A case report. J Pain Symptom Manage 2004; 27:268-273.

90. Compton P, Charuvastra VC, Ling W. Pain intolerance in opioid-maintained former opiate addicts: Effect of longacting maintenance agent. Drug Alcohol Depend 2001; 63:139-146.

91. Ramaekers JG. Antidepressants and driver impairment: Empirical evidence from a standard on-the-road test. J Clin Psychiatry 2003; 64:20-29.

92. Meijler W]. [Driving ban for patients on chronic opioid therapy unfounded]. Ned Tijdschr Geneeskd 2000; 144:16441645.

93. Hanks GW. Morphine sans morpheus. Lancet 1995; 346:652-653.

94. Fishbain DA, Cutler RB, Rosomoff HL, Rosomoff RS. Are opioid-dependent/ tolerant patients impaired in drivingrelated skills? A structured evidencebased review. J Pain Symptom Manage 2003; 25:559-577.

95. Swegle JM, Logemann C. Management of common opioid-induced adverse effects. Am Fam Physician 2006; 74:13471354 .

96. Herndon CM, Jackson KC 2nd, Hallin PA. Management of opioid-induced gastrointestinal effects in patients receiving palliative care. Pharmacotherapy 2002; 22:240-250.

97. Koulousakis A, Kuchta J, Bayarassou A, Sturm V. Intrathecal opioids for intrac- table pain syndromes. Acta Neurochir Supp 2007; 97:43-48.

98. Yuan CS, Foss JF. Antagonism of gastrointestinal opioid effects. Reg Anesth Pain Med 2000; 25:639-642.

99. Sternini C. Receptors and transmission in the brain-gut axis: Potential for novel therapies. III. Mu-opioid receptors in the enteric nervous system. Am J Physiol Gastrointest Liver Physiol 2001; 281: G8-15.

100. Schug SA, Garrett WR, Gillespie G. Opioid and non-opioid analgesics. Best Pract Res Clin Anaesthesiol 2003; 17:91-110.

101. Yuan CS. Methylnaltrexone mechanisms of action and effects on opioid bowel dysfunction and other opioid adverse effects. Ann Pharmacother 2007; 41:984-993.

102. Slappendel R, Simpson K, Dubois D, Keininger DL. Validation of the PAC-SYM questionnaire for opioid-induced constipation in patients with chronic low back pain. Eur J Pain 2006; 10:209-217.

103. Becker G, Galandi D, Blum HE. Peripherally acting opioid antagonists in the treatment of opiate-related constipation: A systematic review. J Pain Symptom Manage 2007; 34:547-565.

104. Tammela T, Kontturi M, Lukkarinen O. Postoperative urinary retention. I. Incidence and predisposing factors. Scand J Urol Nephrol 1986; 20:197-201.

105. O'Riordan JA, Hopkins PM, Ravenscroft A, Stevens JD. Patient-controlled analgesia and urinary retention following lower limb joint replacement: Prospective audit and logistic regression analysis. Eur J Anaesthesiol 2000; 17:431435.

106. Rawal N, Mollefors K, Axelsson K, Lingardh G, Widman B. An experimental study of urodynamic effects of epidural morphine and of naloxone reversal. Anesth Analg 1983; 62:641-647.

107. Malinovsky JM, Le Normand L, Lepage JY, Malinge M, Cozian A, Pinaud M, Buzelin JM. The urodynamic effects of intravenous opioids and ketoprofen in humans. Anesth Analg 1998; 87:456-461.

108. Rosow CE, Gomery P, Chen TY, Stefanovich P, Stambler N, Israel R. Reversal of opioid-induced bladder dysfunction by intravenous naloxone and methylnaltrexone. Clin Pharmacol Ther 2007; 82:48-53.

109. Brunton LL, Lazo JS, Parker KL. Goodman and Gilman's The Pharmacological Basis of Therapeutics, 11th Edition. McGraw-Hill, New York: 2006. 
110. Krantz MJ, Mehler PS. Synthetic opioids and QT prolongation. Arch Intern Med 2003; 163:1615.

111. Walker PW, Klein D, Kasza L. High dose methadone and ventricular arrhythmias: A report of three cases. Pain 2003; 103:321-324.

112. Shah RR. Drug-induced prolongation of the QT interval: Regulatory dilemmas and implications for approval and labelling of a new chemical entity. Fundam Clin Pharmacol 2002; 16:147-156.

113. Katchman AN, McGroary KA, Kilborn MJ, Kornick CA, Manfredi PL, Woosley $\mathrm{RL}$, Ebert SN. Influence of opioid agonists on cardiac human ether-a-go-gorelated gene $\mathrm{K}(+)$ currents. J Pharmacol Exp Ther 2002; 303:688-694.

114. Sanguinetti MC, Jiang C, Curran ME, Keating MT. A mechanistic link between an inherited and an acquired cardiac arrhythmia: HERG encodes the IKr potassium channel. Cell 1995; 81:299-307.

115. Roden DM. Drug-induced prolongation of the QT interval. N Engl J Med 2004; 350:1013-1022.

116. Ehret GB, Voide C, Gex-Fabry M, Chabert J, Shah D, Broers B, Piguet V, Musset T, Gaspoz JM, Perrier A, Dayer P, Desmeules JA. Drug-induced long QT syndrome in injection drug users receiving methadone: High frequency in hospitalized patients and risk factors. Arch Intern Med 2006; 166:1280-1287.

117. Sagie A, Larson MG, Goldberg RJ, Bengtson JR, Levy D. An improved method for adjusting the QT interval for heart rate (the Framingham Heart Study). Am J Cardiol 1992; 70:797-801.

118. Indik JH, Pearson EC, Fried K, Woosley RL. Bazett and fridericia QT correction formulas interfere with measurement of drug-induced changes in QT interval. Heart rhythm 2006; 3:1003-1007.

119. Skjervold B, Bathen J, Spigset O. Methadone and the QT interval: Relations to the serum concentrations of methadone and its enantiomers (R)-methadone and (S)-methadone. J Clin Psychopharmacol 2006; 26:687-689.

120. Pearson EC, Woosley RL. QT prolongation and torsades de pointes among methadone users: Reports to the FDA spontaneous reporting system. Pharmacoepidemiol Drug Saf 2005; 14:747753.

121. Sticherling C, Schaer BA, Ammann P, Maeder M, Osswald S. Methadone-induced Torsade de pointes tachycardias. Swiss Med Wkly 2005; 135:282285.
122. Friedman RA, House JW, Luxford WM, Gherini S, Mills D. Profound hearing loss associated with hydrocodone/acetaminophen abuse. Am J Otol 2000; 21:188-191.

123. Ho T, Vrabec JT, Burton AW. Hydrocodone use and sensorineural hearing loss. Pain Physician 2007; 10:467-472.

124. Wallace M, Skowronski R, Khanna S, Tudor IC, Thipphawong J. Efficacy and safety evaluation of once-daily OROS hydromorphone in patients with chronic low back pain: A pilot open-label study (DO-127). Curr Med Res Opin 2007; 23:981-989.

125. Chamberlin KW, Cottle M, Neville R, Tan J. Oral oxymorphone for pain management. Ann Pharmacother 2007; 41:1144-1152.

126. Portenoy RK, Farrar JT, Backonja MM, Cleeland CS, Yang K, Friedman M, Colucci SV, Richards P. Long-term use of controlled-release oxycodone for noncancer pain: Results of a 3-year registry study. Clin J Pain 2007; 23:287-299.

127. Caldwell JR, Rapoport RJ, Davis JC, Offenberg HL, Marker HW, Roth SH, Yuan W, Eliot L, Babul N, Lynch PM. Efficacy and safety of a once-daily morphine formulation in chronic, moderate-to-severe osteoarthritis pain: Results from a randomized, placebo-controlled, double-blind trial and an open-label extension trial. J Pain Symptom Manage 2002; 23:278-291.

128. Allan L, Richarz U, Simpson K, Slappendel R. Transdermal fentanyl versus sustained release oral morphine in strongopioid naive patients with chronic low back pain. Spine 2005; 30:2484-2490.

129. Portenoy RK, Messina J, Xie F, Peppin J. Fentanyl buccal tablet (FBT) for relief of breakthrough pain in opioid-treated patients with chronic low back pain: A randomized, placebo-controlled study. Curr Med Res Opin 2007; 23:223-233.

130. Raja SN, Haythornthwaite JA, Pappagallo M, Clark MR, Travison TG, Sabeen S, Royall RM, Max MB. Opioids versus antidepressants in postherpetic neuralgia: A randomized, placebo-controlled trial. Neurology 2002; 59:1015-1021.

131. Dellemijn $\mathrm{PL}$, van Duijn $\mathrm{H}$, Vanneste JA. Prolonged treatment with transdermal fentanyl in neuropathic pain. J Pain Symptom Manage 1998; 16:220-229.

132. Maier C, Hildebrandt J, Klinger R, Henrich-Eberl C, Lindena G; MONTAS Study Group. Morphine responsiveness, efficacy and tolerability in patients with chronic non-tumor associated pain- results of a double-blind placebo-controlled trial (MONTAS). Pain 2002; 97:223-233.

133. Roth SH, Fleischmann RM, Burch FX, Dietz F, Bockow B, Rapoport RJ, Rutstein J, Lacouture PG. Around-the-clock, controlled-release oxycodone therapy for osteoarthritis-related pain: Placebocontrolled trial and long-term evaluation. Arch Intern Med 2000; 160:853860.

134. Moulin DE, lezzi A, Amireh R, Sharpe WK, Boyd D, Merskey H. Randomised trial of oral morphine for chronic noncancer pain. Lancet 1996; 347:143-147.

135. Eisenberg E, McNicol E, Carr DB. Opioids for neuropathic pain. Cochrane Database Syst Rev 2006; 3:CDoo6146.

136. Gilron I, Orr E, Tu D, O’Neill JP, Zamora JE, Bell AC. A placebo-controlled randomized clinical trial of perioperative administration of gabapentin, rofecoxib and their combination for spontaneous and movement-evoked pain after abdominal hysterectomy. Pain 2005; 113:191-200.

137. Gimbel JS, Richards P, Portenoy RK. Controlled-release oxycodone for pain in diabetic neuropathy: A randomized controlled trial. Neurology 2003; 60:927-934.

138. Harke H, Gretenkort P, Ladleif HU, Rahman S, Harke O. The response of neuropathic pain and pain in complex regional pain syndrome I to carbamazepine and sustained-release morphine in patients pretreated with spinal cord stimulation: A double-blinded randomized study. Anesth Analg 2001; 92:488495.

139. Morley JS, Bridson J, Nash TP, Miles JB, White S, Makin MK. Low-dose methadone has an analgesic effect in neuropathic pain: A double-blind randomized controlled crossover trial. Palliative Med 2003; 17:576-587.

140. Rowbotham MC, Twilling L, Davies PS, Reisner L, Taylor K, Mohr D. Oral opioid therapy for chronic peripheral and central neuropathic pain. $N$ Engl J Med 2003; 348:1223-1232.

141. Watson CP, Moulin D, Watt-Watson J, Gordon A, Eisenhoffer J. Controlled-release oxycodone relieves neuropathic pain: A randomized controlled trial in painful diabetic neuropathy. Pain 2003; 105:71-78.

142. Huse E, Larbig W, Flor H, Birbaumer N. The effect of opioids on phantom limb pain and cortical reorganization. Pain 2001; 90:47-55. 